\title{
Verrucopapillary Lesions of the Oral Cavity:
} A Review

\section{SANA KHALED'1, SANTOSH R. BHARADWAJ², BUSHRA ANJUM³, D. SATYANARAYANA*4}

Verrucopapillary lesions are a spectrum of benign, potentially malignant and malignant lesions of the oral mucosa which usually are misdiagnosed. They pose a great diagnostic challenge mainly due to confusing terminology and also due to similar clinical and histopathological features which often makes these lesions indistinguishable from one another. The human papilloma virus (HPV) plays a important role in the pathogenesis of majority of these lesions. This review aims to summarize and highlight the key clinical and histopathological features of these lesions, and also provides a diagnostic approach to these entities.

KEYWORDS: Human Papilloma Virus (HPV), Oral mucosa, Malignancy

\section{INTRODUCTION}

Most of the biopsied lesions of the oral mucosa have shown a unique proliferation of the stratified squamous epithelium, with or without inductive changes of the underlying stroma. These proliferations fall into three types: papillary exophytic masses, broad verruciform excesses of surface keratin and flat hyperplasias of spinous cell layer. The exophytic lesions represent as any pathologic growth that projects above the normal contours of the oral surface. The papillary lesions represent swelling with finger like projections imparting a cauliflower like appearance, these micro projections are rounded and blunt like fungiform papillae of the tongue. The verrucous lesions are similar to papillary lesions yet possess a more irregular surface. These papillary or verrucous type lesions are quite common in the oral and paraoral regions, representing $3 \%$ of biopsied oral lesions. Clinical information and an adequate biopsy are essential for making an accurate diagnosis of these lesions, but the primary objective must be to evaluate the epithelium for dysplastic features and signs of invasion. Hence, differentiation between verrucous and papillary lesion is based more on microscopic features rather than the clinical appearance. Biopsy is usually indicated to secure a definitive diagnosis and to follow a proper treatment plan.

\section{PATHOGENESIS}

Majority of verrucous lesions are thought to be induced by viral infection of the epithelium especially Human Papilloma Virus (HPV). Human papilloma viruses are a group of genetically related organisms that infect stratified squamous epithelium. There are more than 120 genetically different, yet closely related HPVs that are referred to as genotypes. Most of the oral and labial papillary lesions are HPV-associated and few are self-limited benign growths that do not progress to cancer, like keratoacanthoma. ${ }^{1}$

\begin{tabular}{|c|c|}
\hline GENOTYPE & LESIONS \\
\hline HPV 2, 4 & Verruca Vulgaris \\
\hline HPV 6, 11 & $\begin{array}{c}\text { Condyloma Acuminatum, } \\
\text { Squamous Papilloma }\end{array}$ \\
\hline HPV 13, 32 & Focal epithelial hyperplasia \\
\hline HPV 16 & $\begin{array}{c}\text { Proliferative Verrucous } \\
\text { Leukoplakia Subtypes }\end{array}$ \\
\hline HPV 6, 11, 16 & Verrucous Carcinoma \\
\hline HPV 16, 18 & Squamous Cell Carcinoma \\
\hline
\end{tabular}

Table 1. Human Papilloma Viruses and Head and Neck lesions ${ }^{1}$

\section{HPV EFFECTS ON ORAL EPITHELIA}

The HPVs induce proliferative changes in oral epithelial cells that result in both benign and malignant tumors and can only infect parabasal or basal cells of the epithelium. Infection may be initiated by micro abrasions on the surface, which 
allows better access for this virus into the basal cells. When the virus initially enters host basal cells, it cannot replicate until the cell matures into a keratinocyte, as the host cell undergoes the normal differentiation, the virus also starts its replication. The virus starts its replication once the host cell mitosis occurs. Then virus expresses its the early proteins--E1, $\mathrm{E}_{2}, \mathrm{E}_{5}, \mathrm{E}_{6}$, and E7--in the lower spinous layers which occurs in the early phases of the infection. As the epithelial cells mature, the cell cycle is halted as part of forming a protective barrier; however, terminal differentiation is hindered by $\mathrm{E} 7$ and E6. This has most likely evolved to allow the host cell to continue to reproduce viruses.

As the host cell life progresses to the upper spinous layer, gene expression of HPV changes. The late proteins--L1 and L2--and $\mathrm{E}_{4}$ are upregulated and at this point, virus assembly occurs and exfoliating cells of the epithelium now releases complete virions. These cells are resilient in dry environments and virions shed from cornified squames have a higher chance of survival. Cornified squames are the epithelial cells that have more keratin which is a protective agent that hardens the cell. HPV then adheres to a specific receptor protein on the keratinocytes membrane in order to be assimilated into the cell by a process known as endocytosis. Once the virus enters into the cell, it divests itself of its protein coat and the viral DNA and then utilizes host cell DNA building blocks to replicate.

These viruses elaborate early gene proteins that are able to regulate the host cell cycle or mitotic capabilities. E6 and $\mathrm{E}_{7}$ proteins are the most important in this respect, as they bind to the host proteins that are regulators of the keratinocytes cell division cycle. E6 binds to a protein designated p53, a molecule that arrest cell division, however once bound, it is degraded and this causes inhibition of keratinocytes mitosis to be nullified. Likewise, E7 binds a protein termed $\mathrm{Rb}$; and it leads to cell cycle regulation disruuption. ${ }^{2}$

E1 - Viral replication

E2 - Regulates viral transcription and replication

$\mathrm{E}_{4}$ - Interacts with cytoskeletal proteins

E5 - Downregulation of MHC Class 1 molecules

E6 - Oncoprotein, binds to tumor suppressor protein

p53

E7 - Oncoprotein, binds to tumor suppressor protein retinoblastoma $(\mathrm{Rb})$

$\mathrm{L} 1$ - Major viral caspid protein
L2 - Minor viral caspid protein

\section{ANATOMICAL LANDMARKS RESEMBLING VERRUCOUS-PAPILLARY LESIONS}

Some of the normal anatomic structures in the oral cavity, presenting as a papillary pattern are accessory tonsillar tissue, filiform papillae, fungiform papillae, foliate papillae, circumvallate papillae, retrocuspid, retromolar papillae and stensens's papillae. Sometimes, these structures attain such a size that they are mistaken for pathoses. The anatomic locations of the structures, however, usually enable immediate recognition. ${ }^{3}$

\section{CLASSIFICATIONS OF VERRUCOUS- PAPILLARY LESIONS}

(A) According to Regezi JA et al, Verrucous lesions of the oral cavity are classified into: 4

I. Reactive/Infectious Lesions

- Squamous papilloma/Oral Wart

- Inflammatory Papillary Hyperplasia

- Condyloma Acuminatum

- Condyloma Latum

- Focal Epithelial Hyperplasia (Heck's Disease)

- Molluscum Contagiosum

II. Neoplasms \& Pre-malignant Lesions

- Keratoacanthoma

- Giant Cell Fibroma

- Verrucous Hyperplasia

- Proliferative Verrucous Leukoplakia

- Verrucous Carcinoma

- Papillary squamous Cell Carcinoma

- Sialadenoma Papilliferum

III. Idiopathic/Miscellaneous Lesions

- Pyostomatitis Vegetans

- Verruciform Xanthoma

- Dariers Disease

- Warty Dyskeratoma

(B) According to Gareth J Thomas, A William Barrette, Papillary and Verrucous lesions of the oral mucosa are classified into: ${ }^{5}$

I. Benign

- Viral papillomas:

- Squamous papilloma

- Verruca vulgaris

- Condyloma acuminatum

- Focal epithelial hyperplasia

- Reactive Verrucous and papilla-nodular lesions:

- Fibro-epithelial polyps

- Verruciform xanthoma 
- Papillary hyperplasia

- Pyostomatitis vegetans

- Sialadenoma papilliferum

- Acanthosis nigricans

- Darier's disease

II. Potentially Malignant:

- Verrucous hyperplasia

- Papillary dysplasia

- Proliferative (verrucous) leukoplakia

III. Malignant:

- Verrucous carcinoma

- Papillary carcinoma:

$\circ$ Non-invasive (synonymous with papillary dysplasia)

- Invasive (essentially a conventional squamous cell carcinoma requiring treatment as such)

- Carcinoma cuniculaturn (essentially a conventional, well differentiated squamous cell carcinoma requiring treatment as such)

(C) According to Eversole LR, Papillary, papular, and multiple polypoid lesions are classified into: ${ }^{6}$

1. Focal Papillary lesions

- Squamous papillorna

- Verruca vulgaris

- Condyloma acuminatum

- Verrciform xanthoma

- Sialadenoma papilliferum

- Giant cell Fibroma

2. Focal and Umbilicated papules

- Keratoacanthoma

- Warty dyskeratoma

- Molluscum contagiosum

3. Diffuse and multifocal papillary lesions

- Condyloma Acuminatum

- Focal dermal Hypoplasia

- Nevus unius Lateris

- Oral florid papillomatosis

- Verrucous leukoplakia

- Verrucous carcinoma

4. Diffuse Papular and Polypoid lesions

- Papillary hyperplasia

- Keratosis follicularis

- Focal epithelial hyperplasia

- Pyostomatitis Vegetans

- Crohn's disease

\section{DIAGNOSIS OF VERRUCOUS-PAPILLARY LESIONS}

Usually clinical appearance and characteristic histopathologic features are useful for the diagnosis of verrucous papillary lesions. Occasionally, other diagnostic tools are also needed for the definitive diagnosis of few of these entities. Special stains are used for molluscum bodies in molluscum contagiosum are stained by Feulgen staining which demonstrates DNA-containing viral inclusions as Magenta, in Verruciform Xanthoma, acanthotic epithelial process, may assume an unusual orange color in $\mathrm{H}$ \& $\mathrm{E}$ stained slides. In addition, large foamy cells with diastase- resistant, PAS positive granules fill the papillary corium and cytological smears may show presence of koilocytes, especially of PAP smears. Ultrastructural studies such as use of electron microscopy enables visualization of HPV particles in verrucous lesions associated by HPV. These HPV viral particles appear in scattered form within the nuceli of the affected epithelial cells. However, due to its low sensitivity, electron microscopy has merely historical diagnostic value.

Furthermore, even if HPV particles are detected, an identification of the specific HPV genotype present is not possible. ${ }^{9}$ Immunohistochemical (IHC) studies are also done as they are found to be most consistent and reproducible traditional method for HPV detection. IHC of papilloma virus structural proteins may confirm the presence particular HPV genotype. However, inconsistence in antigen detection may result from sampling error, and destruction of antigens during tissue processing or lengthy storage.9 However, there are recent molecular methods being considered at present as a key tool in the detection of HPV in verrucous-papillary lesions. The molecular methods which enable the detection of viral DNA in tissue morphology content such as In situ hybridization which detects HPV in tissue specimens and those in which tissue destruction is unavoidable for detection of HPV DNA such as Polymerase chain reaction (PCR) which is currently the most sensitive method for HPV detection. However, because of frequent contamination problem, it should be applied in diagnostic settings with great caution. ${ }^{9}$

\section{SUMMARY AND CONCLUSION}

The diagnosis of benign, reactive verrucous and 


\section{ORAL MANIFESTATIONS AND HISTOPATHOLOGICAL FEATURES OF VERRUCOPAPILLARY LESIONS $^{2,4,7,8}$}

\begin{tabular}{|c|c|c|}
\hline LESIONS & ORAL MANIFESTATIONS & HISTOPATHOLOGICAL FEATURES \\
\hline $\begin{array}{l}\text { Squamous } \\
\text { Papilloma }\end{array}$ & $\begin{array}{l}\text { Exophytic lesion with numerous fingerlike } \\
\text { surface projections, cauliflowerlike or wartlike } \\
\text { appearance, pedunculated }\end{array}$ & $\begin{array}{l}\text { Finger like projections of epithelium with } \\
\text { fibrovascular core, acanthosis, koliocytes, }\end{array}$ \\
\hline Verruca Vulgaris & $\begin{array}{l}\text { Papule or nodule with papillary projections or } \\
\text { rough pebbly surface, pointed narrow stalk }\end{array}$ & $\begin{array}{l}\text { Finger like projections of epithelium with } \\
\text { connective tissue core, reteridges converging - } \\
\text { Cupping effects, prominent granular cell layer, } \\
\text { koliocytes }\end{array}$ \\
\hline $\begin{array}{l}\text { Inflammatory } \\
\text { Papillary } \\
\text { Hyperplasia }\end{array}$ & $\begin{array}{c}\text { Erythematous or edematous papillary } \\
\text { projections - Cobble stone appearance, focal } \\
\text { telangiectatic sites }\end{array}$ & $\begin{array}{l}\text { Para/Orthokeratosis, central core of connective } \\
\text { tissue, pseudo-epitheliomatous hyperplasia, } \\
\text { severe inflammatory cell infiltrate }\end{array}$ \\
\hline $\begin{array}{l}\text { Condyloma } \\
\text { Acuminatum }\end{array}$ & $\begin{array}{c}\text { sessile, pink, well demarcated, nontender } \\
\text { exophytic mass with short, blunt surface } \\
\text { projections giving it a "Raspberry or Mulberry" } \\
\text { appearance. }\end{array}$ & $\begin{array}{l}\text { Parakeratotic papillary surface projections, } \\
\text { keratin filled crypts between prominences, } \\
\text { acanthosis, koliocytes, vacuolated cells }\end{array}$ \\
\hline Condyloma Latum & $\begin{array}{l}\text { soft red, often mushroom like mass with a } \\
\text { generally smooth lobulated surface }\end{array}$ & $\begin{array}{c}\text { Acanthosis, intra/intercellular edema, } \\
\text { transmigration of neutrophils, perivascular } \\
\text { plasma cell infiltrate }\end{array}$ \\
\hline $\begin{array}{l}\text { Heck's Disease/ } \\
\text { Focal Epithelial } \\
\text { Hyperplasia }\end{array}$ & $\begin{array}{c}\text { Soft, nontender, flattened or rounded papules, } \\
\text { broad based, sessile with multiple clustered } \\
\text { plaques }\end{array}$ & $\begin{array}{l}\text { Focal acanthosis, lack of connective tissue core, } \\
\text { reteridges widened - club shaped, presence of } \\
\text { mitosoid cells }\end{array}$ \\
\hline $\begin{array}{l}\text { Molluscum } \\
\text { Contagiosum }\end{array}$ & $\begin{array}{l}\text { Hemispheric lesions with central umbilication, } \\
\text { single or multiple discrete elevated nodules }\end{array}$ & $\begin{array}{l}\text { Thickening and downgrowth of epithelium, } \\
\text { presence of molluscum bodies }\end{array}$ \\
\hline $\begin{array}{l}\text { Fibroepithelial } \\
\text { Polyps }\end{array}$ & $\begin{array}{l}\text { Small, round, pink, red or white knob-like } \\
\text { growth, pedunculated }\end{array}$ & $\begin{array}{l}\text { Sessile or pedunculated lesion with seborrheic } \\
\text { keratosis like hyperplasia of epidermis, } \\
\text { increased vascularity }\end{array}$ \\
\hline $\begin{array}{l}\text { Acanthosis } \\
\text { Nigricans }\end{array}$ & $\begin{array}{l}\text { Hypertrophy of filiform papillae - shaggy, } \\
\text { papillomatous surface }\end{array}$ & $\begin{array}{l}\text { Basket-weave hyperkeratosis papillomatosis, } \\
\text { irregular acanthosis, fused reteridges, dermal } \\
\text { papillae-finger like projections filled with } \\
\text { keratotic material, pseudohorn cysts }\end{array}$ \\
\hline $\begin{array}{l}\text { Focal Dermal } \\
\text { Hypoplasia }\end{array}$ & $\begin{array}{l}\text { Focal absence of dermis with herniation of } \\
\text { subcutaneous fat, multiple papillomas }\end{array}$ & $\begin{array}{l}\text { Fibrovascular stalk composed of loose } \\
\text { connective tissue with dilated vessels }\end{array}$ \\
\hline Nevus Unius Lateris & Pebbly papillary pattern & $\begin{array}{l}\text { Acanthosis, hyperkeratosis, papillomatosis, } \\
\text { elongated rete ridges, parakeratotic columns, } \\
\text { hyperpigmentation in basal layer }\end{array}$ \\
\hline
\end{tabular}

Table 2. Reactive/Infectious Lesions 
Keratoacanthoma

Giant Cell Fibroma
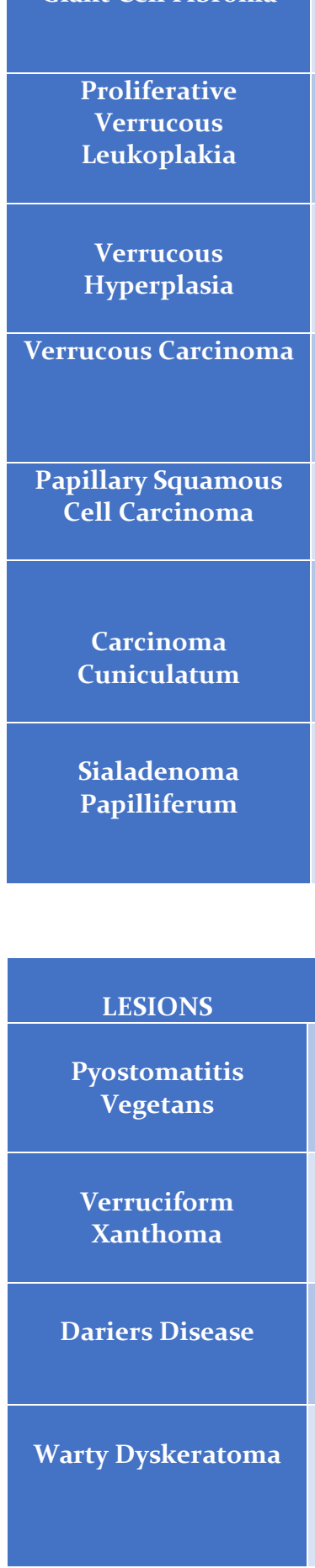

Firm, non-tender, well demarcated, sessile dome shaped nodule with central keratin plug

Sessile or pedunculated nodule with a lobulated or somewhat papillary surface

Solitary flat white keratotic lesion with a grainy or Verrucous surface or transformation from flat into exophytic and wart-like lesions, erythroplakic change

Varying degrees of epithelial dysplasia

Exophytic slow growth producing cauliflower like warty lesion which is locally aggressive and well circumscribed

Exophytic papillary proliferation but it lacks the prominent surface keratinization

Warty mass like appearance

Well circumscribed painless, papillary or verrucoid lesion, base of the lesion is board or pedunculated
HISTOPATHOLOGICAL FEATURES

Ortho/parakeratin formation, hyperplastic acanthotic epithelium, central keratin plug with an overhanging marginal buttress of epithelium, chronic inflammatory cell infiltrate

Surface epithelium is thin, corrugated and atrophic, with narrow and elongated rete ridges, in CT there are large, plump, spindle- shaped and stellate fibroblasts

Enhanced acanthosis, basilar hyperplasia, abrupt transition from hyperparakeratosis to hyperorthokeratosis, Civatte bodies are found

Sharp (narrow projections which are heavily keratinized) and Blunt (broader, shorter projections less keratinzed or nonkeratinzed) variants are found, blunt rete ridges

Epithelial proliferation with downgrowth of epithelium into the connective tissue, dysplastic

features and parakeratin plugging are seen

Exophytic proliferation of malignant appearing squamous cells covering the papillae with fibrovascular cores

Keratinizing, endophytic and variably exophytic epithelial mass, with a cohesive rete pattern invaginated into the tissues, microabscess formation

Exophytic and endophytic proliferation of ductal epithelium, surface has a papillary to verrucoid growth pattern, interpapillary clefts seen, ductal epithelial cells show eosinophilic and oncocytic features

Table 3. Neoplasms and Pre-Malignant Lesions

\section{ORAL MANIFESTATIONS}

\section{HISTOPATHOLOGICAL FEATURES}

Erythematous, edematous, nodular or fissured, areas of ulcerations are formed which later coalesce - snail tract ulcerations

Papillary/granular or verrucous with a sessile or pedunculated base, center of the lesion can appear depressed, cup-shaped or crateriform with or without ulceration

Small whitish papules, producing an overall cobblestone appearance.
Hyperkeratosis, acanthosis, often with a papillary surface or/with pseudo epitheliomatous hyperplasia, superficial abscesses are seen

Verruciform or papillary surface changes, often with clefts or crypts between the epithelial projections, parakeratin surface layer, elongated rete ridges

Hyperkeratosis, papillomatosis, acanthosis, benign dyskeratosis is characterized by rather typical cells called corps, ronds and grains

Central orthokeratin or parakeratin core beneath which the epithelium shows a Small whitish area of mucosa with central depression suprabasilar separation resulting in a cleft like space containing acantholytic and benign dyskeratotic cells

Table 4. Idiopathic/Miscellaneous Lesions 


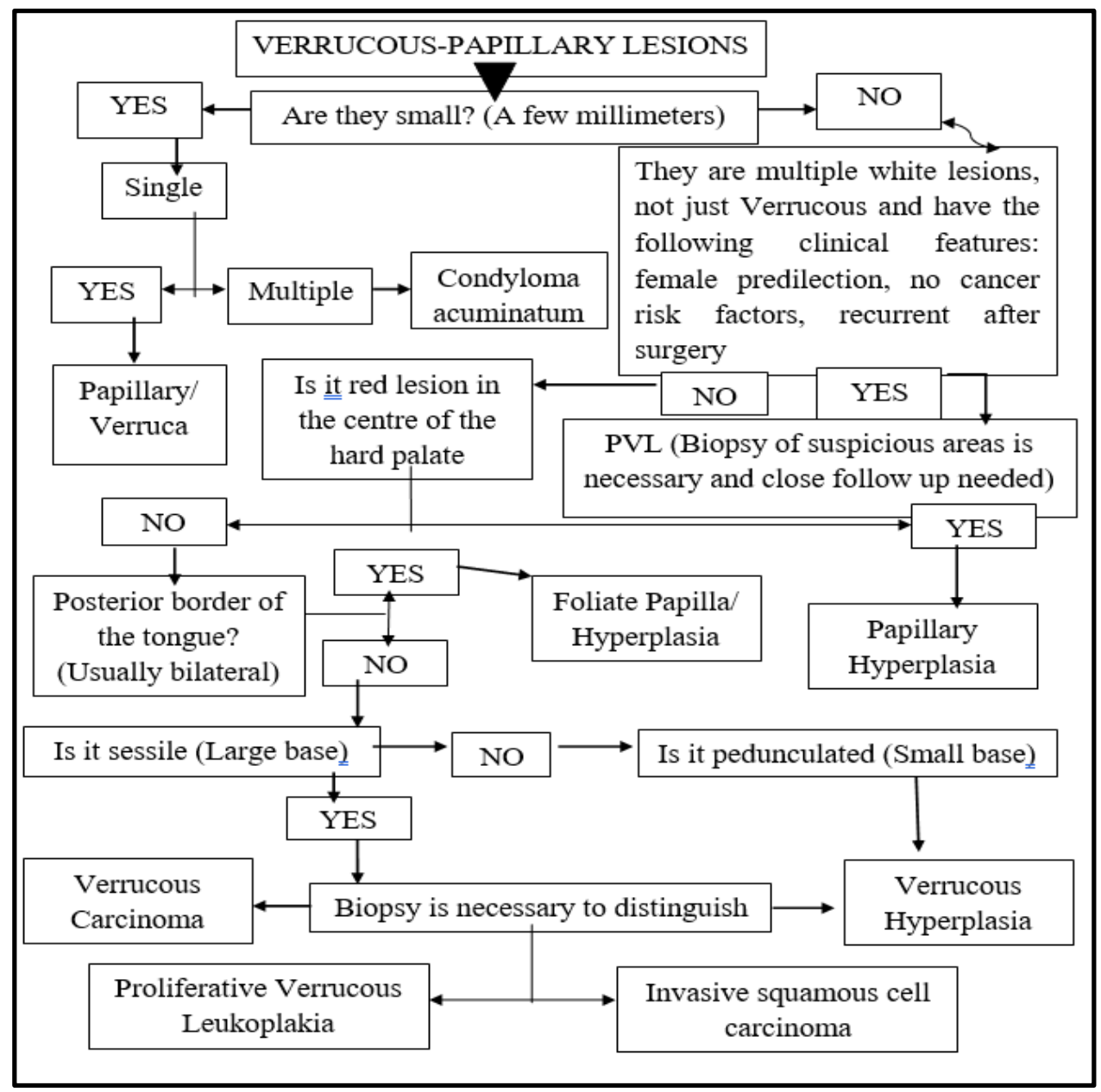

Figure 1. Diagnostic Flowchart of Verrucous-Papillary Lesions of the Oral Cavity

papillary oral lesions usually little difficult, whereas the lesions with their dysplastic counterparts unless the lesion is at either end of the spectrum of verrucous hyperplasia and verrucous carcinoma cane be diagnosed with characteristic histopathlogical features. HPV is found to be associated with majority of these lesions. HPV effects the oral epithelium causing various proliferative and dysplastic changes in the epithelium. There are few lesions like papillary hyperplasia, verruciform xanthoma, cowden syndrome, nevus unius lateris, acanthosis nigricans which are without known viral association. Many of these lesions have overlapping features both clinically and microscopically, therefore proper examination of the lesion followed by biopsy and in some cases special diagnostic methods are to be done for accurate diagnosis.

\section{REFERENCES}

1. Eversole LR. Papillary lesions of the oral cavity: relationship to human papillomaviruses. Journal of the California Dental Association 2000; 28: 922-7.

2. Syrjanen S. Oral manifestations of human papillomavirus infections. Eur J Oral Sci. 2018; 126(Suppl. 1): 49-66. https://doi.org/10.1111/eos.12538 3. Wood NK, Goaz PW. Differential diagnosis of Oral and Maxillofacial lesions, $5^{\text {th }}$ edition, 1998. Mosby Inc. 4. Regezi JA, Sciubba JJ, Jordan RCK. Oral Pathology clinical pathological correlations. $5^{\text {th }}$ edition. Saunders 2008.

5. Thomas GJ, Barrett AW. Papillary and Verrucous lesions of the oral mucosa Diagnostic Histopathology 2009;15: 279-85.

6. Eversole LR. Clinical outline of oral pathology: 
Diagnosis and treatment, $3^{\text {rd }}$ edition. 1992. Lea \& Febiger, Philadelphia.

7. Rajendran R, Sivapathasundharam B. Shafer's text book of oral pathology. 8th edition. New Delhi: Elsevier; 2016

8. Neville BW, Damm DD, Allen CM, Bouquot JE. Oral \& maxillofacial pathology. 1st South India Edition. New
Delhi: Elsevier; 2015.

9. Thompson LDR. Head and neck pathology a volume in series foundations in Diagnsotic pathology. Churchhill Livingstone, 2006: 34-6.

10. Gandolfo S, Scully C, Carrozzo M. Oral Medicine. Churchhill Livingstone Elsevier, 2006: 32-3.

Cite this article as:

Khaled S, Bharadwaj SR, Anjum B, Satyanarayana D. Verrucopapillary Lesions of the Oral Cavity:

Source of support: Nil, Conflict of interest: None declared

A Review. Int Healthc Res J. 2020;4(7):RV1-RV7. https://doi.org/10.26440/IHRJ/0407.10365

\section{AUTHOR AFFILIATIONS: (*Corresponding Author)}

1. Assistant Professor, Master of Dental Surgery, Department of Oral and Maxillofacial Pathology, Sri Balaji Dental College, Hyderabad,

\section{Telangana}

2. Assistant Professor, Master of Dental Surgery, Department of Orthodontics and Dentofacial Orthopedics, HKES, Nijalingappa Institute

of Dental Sciences, Gulbarga, Karnataka

3. Assistant Professor, Master of Dental Surgery, Department of Oral and Maxillofacial Pathology, Panineeya Institute of Dental Sciences \& RC Hyderabad, Telangana

4. Associate Professor, Master of Dental Surgery, Department of Public Health Dentistry, Panineeya Institute of Dental Sciences \& RC Hyderabad, Telangana

Contact corresponding author at: satya.gullu[at]gmail[dot]com 